\title{
Comparative study for some antioxidants in correction of oxidative stress markers for experimental induced diabetic rabbits
}

\author{
A. J. Abd \\ Coll. of Sci./ Unive. \\ Al-Muthana
}

\author{
B. J. Mohammed \\ Coll. of Vet. Med. \\ / Unive.Al-Qadysia
}

\author{
D. A. Aziz \\ Coll. of Sci./ Unive. of \\ Al-Muthana
}

Determination of reliable biochemical parameters of experimental diabetic rabbit by alloxane monohydrates and role of diatery antioxidants (ascorbic acid, vit. A, and $\alpha$ tocopherole) supplementation were investigated. Body weight gain, blood (plasma) chemistries, antioxidant enzymes and histopathological lesion were determined over 10 week in new Zealand white rabbits: control T1 group, diabetic T2 group, diabetic and ascorbic acid T3 group, diabetic and Vit. A T4 group, diabetic and $\alpha$-tocopherole T5 animals group . each of dietary ascorbic acid, vit. A and $\alpha$-tocopherole that given to animals of T3, T4 and T5 respectively were significantly $(\mathrm{P} \leq 0.01)$ reduced glucose level in blood than $\mathrm{T} 2$ diabetic group, also these antioxidants improve levels of cholesterol and triglyceride. Enzymatic activity of liver glutathione peroxidase and superoxide dismutase were significantly increasd more than of diabetic animals T2. histopathological structures of liver and pancrease confirm these results which indicate mild congestion and less degenerative signs in hepatocytes with mild degeneration of langerhans islets, generally oxidative stress resulted from diabetes and may diminished by administration of antioxidant ascorbic acid, Vit. A and $\alpha$-tocopherole supplementation, and $\alpha$-tocopherole group was the best group.

\section{Introduction}

Diabetes mellitus, a common metabolic disorder resulting from defects in insulin secretion or action or both, is characterized by hyperglycemia often accompanied by glycosuria, polydipsia, and polyuria $^{(1)}$. During diabetes, persistent hyperglycemia causes increased production of free radicals especially reactive oxygen species (ROS), for all tissue from glucose auto-oxidation and protein glycosylation ${ }^{(2)}$.Free radicals are generated as by-products of normal cellular metabolism, however, several conditions are known to disturb the balance between ROS production and cellular defence mechanism. This imbalance can result in cell dysfunction and destruction resulting in tissue injury, the increase in the level of ROS in diabetes could be due to their increased production and/or decrease destruction by nonenzymatic and enzymatic catalase (CAT), glutathione peroxidase (GSH-px) and superoxide dismutase (SOD) antioxidants the level of these antioxidant enzymes critically influences the susceptibility of various tissues to oxidative stress and is associated with the development of complication in diabetes. Also this is particularly relevant and dangerous for the beta islet, which is among those tissues that have the lowest levels of intrinsic antioxidant defenses ${ }^{(3)}$. On the one hand hyperglycemia engenders free radicals, on the other hand it also impairs the endogenous antioxidant defense system in many ways during diabetes (4). Antioxidant defense mechanisms involve both enzymatic and nonenzymatic strategies. Common antioxidants include the vitamins $\mathrm{A}, \mathrm{C}$, and $\mathrm{E}$, glutathione, and the enzymes superoxide dismutase, catalase, glutathione peroxidase, and glutathione reductase.Vitamins $\mathrm{A}, \mathrm{C}$, and $\mathrm{E}$ are dietderived and detoxify free radicals directly. They also interact in recycling processes to generate reduced forms of the vitamins ${ }^{(5)}$. Tocopherol is reconstituted when ascorbic acid recycles the tocopherol radical; dihydroascorbic acid, which is generated, is recycled by glutathione. These vitamins also foster toxicity by producing prooxidants under some conditions. 
Vitamin E, a component of the total peroxyl radical-trapping antioxidant system, reacts directly with peroxyl and superoxide radicals and singlet oxygen and protects membranes from lipid peroxidation. The deficiency of vitamin $\mathrm{E}$ is concurrent with increased peroxides and aldehydes in many tissues ${ }^{(6)}$. There have been conflicting reports about vitamin $\mathrm{E}$ levels in diabetic animals and human subjects. Plasma and/or tissue levels of vitamin $\mathrm{E}$ are reported to be unaltered ${ }^{(7)}$,

\section{Materials and methods}

Animals:

Following a 7 days acclimation period, 50 juvenile female and male, new zealand (NZW) rabbits were fastened for about $12 \mathrm{hrs}$ then injected with alloxane monohydrate (BHD-England) $(100 \mathrm{mg} / \mathrm{kg}$ body weight $)$ via marginal ear vein in order to induce type 1 diabetes mellitus. blood hyperglycemia was measured after 3 days for checking the occurrence of diabetes onset.Rabbits were randomly separated into five treated groups each include ten animals (T1) control normal, (T2) diabetes group treated only with alloxane monohydrate 100 $\mathrm{mg} / \mathrm{kg}$, (T3) diabetes and vitamin C group treated with alloxane monohydrate then supplemented orally with two doses of ascorate $21 \mathrm{mg} / \mathrm{kg}$ with $10 \mathrm{hrs}$ intervals between each dose, (T4) diabetes and vitamin A group treated with alloxane monohydrate then ditary supplemented with $2000 \mathrm{IU} / \mathrm{kg}$ vit A. (T5) diabetes and $\alpha$-tocopherole group treated with alloxane monohydrate then ditary supplemented with $500 \mathrm{mg} / \mathrm{kg} \alpha$-tocopherole.

\section{Sample collection:}

Initially body weight was obtained prior to induction of diabetes or antioxident supplementation. Subsequently body weight gain and samples

After three days alloxane treated rabbits were indeed diabetic as indicated by plasma glucose level greater than 200 $\mathrm{mg} / \mathrm{dl}$ and remain hyperglycemic throughout the last week of experiment. Table (1) showed that body weight gain increased $^{(8)}$, or decreased ${ }^{(9)}$ by diabetes. Discrepancies among studies in terms of preventive or deleterious effects of vitamin $E$ on diabetes induced vascular aberrations may arise from the variety of examined blood vessels or the administered dose of vitamin E.

\section{Aim of study:}

This study was conducted to identify the role of oxidative stress markers in oxidative stress correction associated with type 1 diabetes mellitus in rabbits

measurements were taken at 10 weeks, whole blood was collected via cardiac puncture from anasthesized (ketamine $50 \mathrm{mg} / \mathrm{kg}$-xylazine $10 \mathrm{mg} / \mathrm{kg}$ ) ${ }^{(10)}$, rabbit were then euthanized with a single cardiac injection fatal plus (concentrated pentobarbital, $360 \mathrm{mg} / \mathrm{kg}$ ).Liver and pancreas tissues were collected for histological studies, while some liver tissues homogenized on ice for 20 second then centrifuged at $30000 \mathrm{cc}$ for 30 minutes at $4^{\circ} \mathrm{c}$ and the supernatant collected for laboratory studies (oxidative stress enzymes).

\section{Blood chemistries}

Glucose in blood, cholesterol and triglyceride concentration in plasma were determined using commercially available kit (sigma), glutathione peroxidase determined as in paglia and valentine method 1967, while total superoxide dismutase (SOD) activity was determined in plasma and liver according to a modified assay described by Pence and Naylor $1990^{(11)}$.

\section{Statistical analysis}

Mean \pm SE was carried. All data are analyzed using Duncan's multiple range test ${ }^{(12)}$ to determine if the treatment were significantly $(\mathrm{P} \leq 0.01)$ different or not.

\section{Results}

and glucose level in T3, T4 and T5 were significantly $(\mathrm{P} \leq 0.01)$ lower than that $\mathrm{T} 2$ group but at the same time glucose level of these groups was significantly higher than $\mathrm{T} 1$ group. There is no significance variation between $\mathrm{T} 3$ and $\mathrm{T} 5$ neither 
between T3 and T4 groups, while glucose level of T3 and T5 groups were significantly lower $(\mathrm{P} \leq 0.01)$ than $\mathrm{T} 4$ group.Table (1) also showed that cholesterol and triglyceride levels in $\mathrm{T} 2$ were significantly higher $(\mathrm{P} \leq 0.01)$ than $\mathrm{T} 3$, T4 and T5, on the other hand there is no significant variation in the level of cholesterol between all antioxidant treatment groups, while triglyceride in T5 group was significantly reduced than $\mathrm{T} 3$ and $\mathrm{T} 4$ groups, there is no significant variation between triglyceride level of $\mathrm{T} 3$

Table 1 explain role of dietary ascorbic acid, Vit.A and $\alpha$-tocopherole on different biochemical parameters of diabetic rabbit

\begin{tabular}{|c|c|c|c|c|c|}
\hline $\begin{array}{c}\text { biochemical } \\
\text { parameters }\end{array}$ & $\begin{array}{c}\text { T1 normal } \\
\text { group }\end{array}$ & $\begin{array}{c}\text { T2 diabetic } \\
\text { only }\end{array}$ & $\begin{array}{c}\text { T3 Vit. C } \\
\text { diabetic }\end{array}$ & $\begin{array}{c}\text { T4 Vit. A } \\
\text { diabetic }\end{array}$ & $\begin{array}{c}\text { T5 } \alpha- \\
\text { tocopherole } \\
+ \text { diabetic }\end{array}$ \\
\hline $\begin{array}{c}\text { Body weight } \\
\text { gain }\end{array}$ & $\begin{array}{c}1.5 \pm 0.091 \\
\mathrm{~d}\end{array}$ & $\begin{array}{c}0.225 \pm 0.03 \\
\mathrm{a}\end{array}$ & $\begin{array}{c}0.63 \pm 0.02 \\
\mathrm{bc}\end{array}$ & $\begin{array}{c}0.51 \pm 0.03 \\
\mathrm{~b}\end{array}$ & $\begin{array}{c}0.875 \pm 0.067 \\
\mathrm{c}\end{array}$ \\
\hline Glucose & $\begin{array}{c}172.4 \pm 1.359 \\
\mathrm{a}\end{array}$ & $\begin{array}{c}389.4 \pm 8.66 \\
8 \mathrm{~d}\end{array}$ & $\begin{array}{c}265.8 \pm 2.303 \\
\mathrm{~b}\end{array}$ & $\begin{array}{c}342 \pm 8.666 \\
\mathrm{c}\end{array}$ & $\begin{array}{c}247 \pm 2.38 \\
\mathrm{~b}\end{array}$ \\
\hline Cholesterol & $\begin{array}{c}72.3 \pm 1.961 \\
\mathrm{a}\end{array}$ & $\begin{array}{c}149.9 \pm 2.90 \\
7 \mathrm{c}\end{array}$ & $\begin{array}{c}91.1 \pm 1.642 \\
\mathrm{~b}\end{array}$ & $\begin{array}{c}97.2 \pm 4.855 \\
\mathrm{~b}\end{array}$ & $\begin{array}{c}93.4 \pm 0.541 \\
\mathrm{~b}\end{array}$ \\
\hline Triglyceride & $\begin{array}{c}76.2 \pm 1.942 \\
\mathrm{a}\end{array}$ & $\begin{array}{c}238 \pm 3.666 \\
\mathrm{~d}\end{array}$ & $\begin{array}{c}98 \pm 2.211 \\
\mathrm{c}\end{array}$ & $\begin{array}{c}176.5 \pm 2.362 \\
\mathrm{c}\end{array}$ & $\begin{array}{c}101.2 \pm 5.401 \\
\mathrm{~b}\end{array}$ \\
\hline $\begin{array}{c}\text { Glutathione } \\
\text { peroxidase }\end{array}$ & $\begin{array}{c}460.5 \pm 45.27 \\
3 \mathrm{~d}\end{array}$ & $\begin{array}{c}142.5 \pm 3.67 \\
\mathrm{a}\end{array}$ & $\begin{array}{c}223.9 \pm 1.206 \\
\mathrm{~b}\end{array}$ & $\begin{array}{c}170.8 \pm 2.878 \\
\mathrm{ab}\end{array}$ & $\begin{array}{c}345.3 \pm 8.811 \\
\mathrm{c}\end{array}$ \\
\hline $\begin{array}{c}\text { Superoxide } \\
\text { dismutase }\end{array}$ & $\begin{array}{c}119.5 \pm 2.733 \\
\mathrm{~d}\end{array}$ & $\begin{array}{c}53 \pm 1.527 \\
\mathrm{a}\end{array}$ & $\begin{array}{c}95 \pm 3.496 \\
\mathrm{c}\end{array}$ & $\begin{array}{c}75.1 \pm 1.1 \\
\mathrm{~b}\end{array}$ & $\begin{array}{c}101.8 \pm 2.164 \\
\mathrm{c}\end{array}$ \\
\hline
\end{tabular}

Results are expressed as mean \pm standard error.

a: no significant variation

Different letters between groups refer to significant variation under probability $(\mathrm{p}<0.01)$.

Degree of freedom: 4, 36

These results were supported by histopathological examination of liver and pancreas.Results indicate marked improvement in T3, T4, and T5 groups as compared with $\mathrm{T} 2$ group, the biochemical finding of study are confirmed with histopathological alteration observed in the and T4 groups.Glutathione peroxidased and superoxide dismutase activity in $\mathrm{T} 1$ were significantly higher $(\mathrm{P} \leq 0.01)$ than all treatment groups as present in table (1), at the same time glutathione peroxidase level in T5 was significantly higher than T2, T3 and $\mathrm{T} 4$, there is no significant differences between $\mathrm{T} 3$ and $\mathrm{T} 4$ and between $\mathrm{T} 2$ and T4. Superoxide dismutase level in T3 and T5 groups significantly did not differ but these two groups were significantly higher $(\mathrm{P} \leq 0.01)$ then $\mathrm{T} 4$ as explaining. 


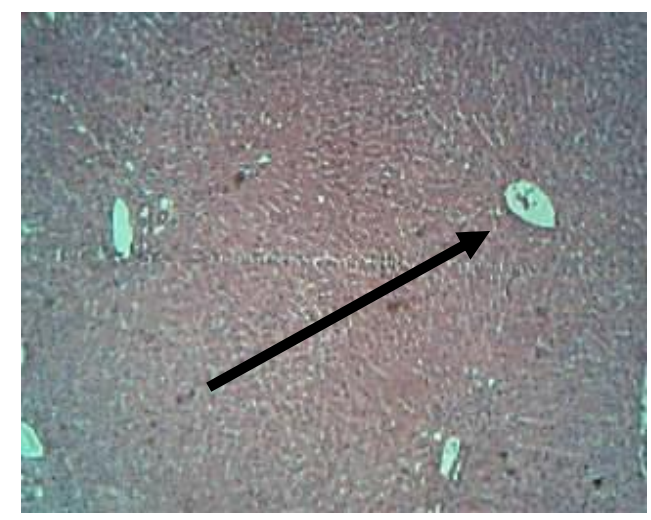

Fig 1 (A)

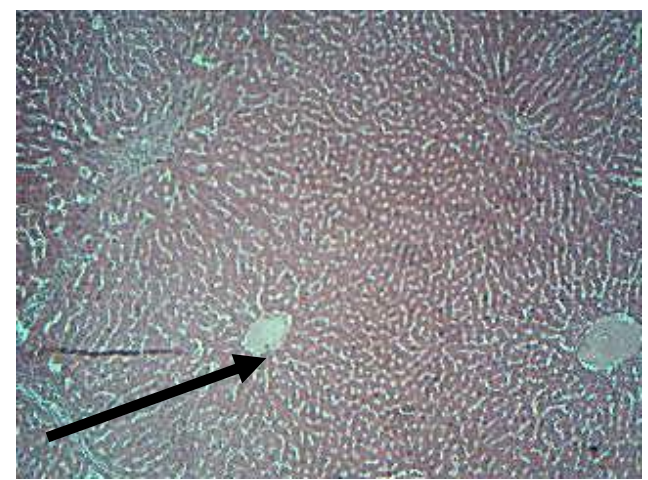

Fig 1 (B)

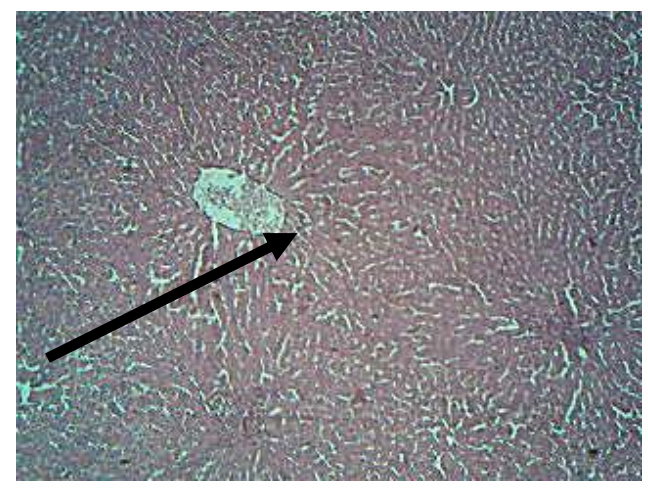

Fig $1(\mathrm{C})$

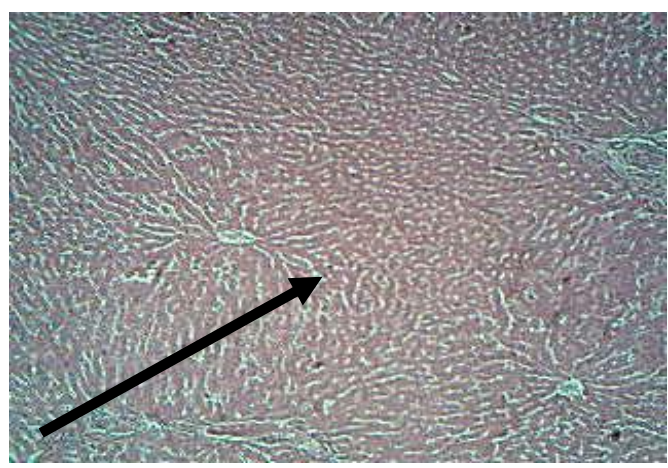

Fig 1 (D)

Photomicrographs of haematoxylin and eosin stained sections of rabbit liver; (A) Group represented a severe congestion of the hepatic tissue with dilation of central vein arrow, necrosis and fibrosis also present (B), (C) and (D) groups showed a moderate congestion and dilation of central vein with less degenerative signs in hepatocytes. (H\&E, 10x). 


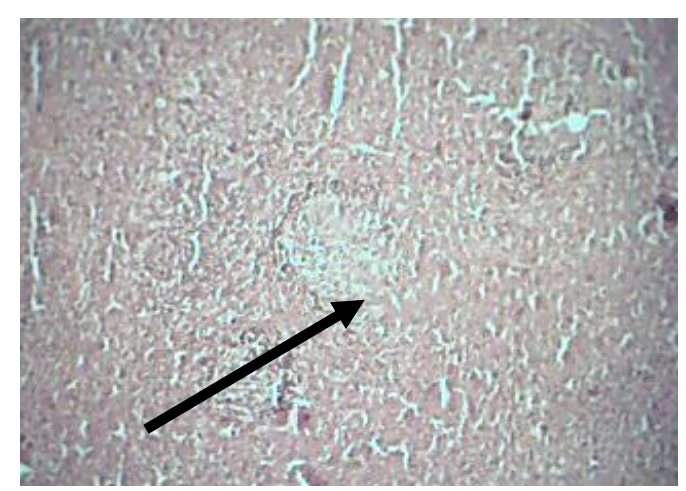

Fig $2(\mathrm{~A})$

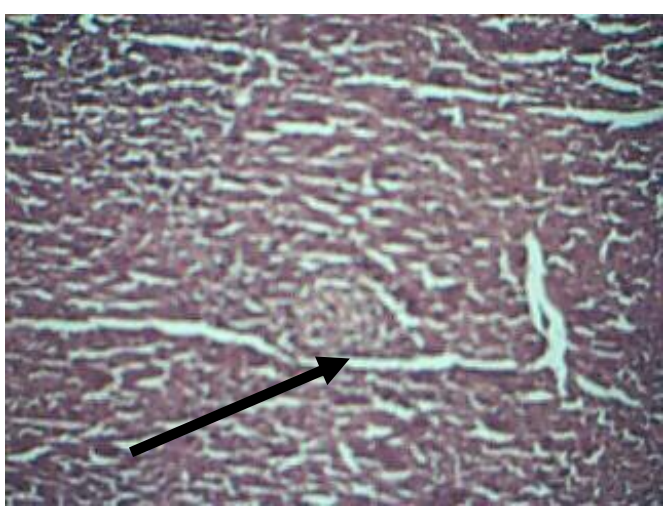

Fig 2(B)

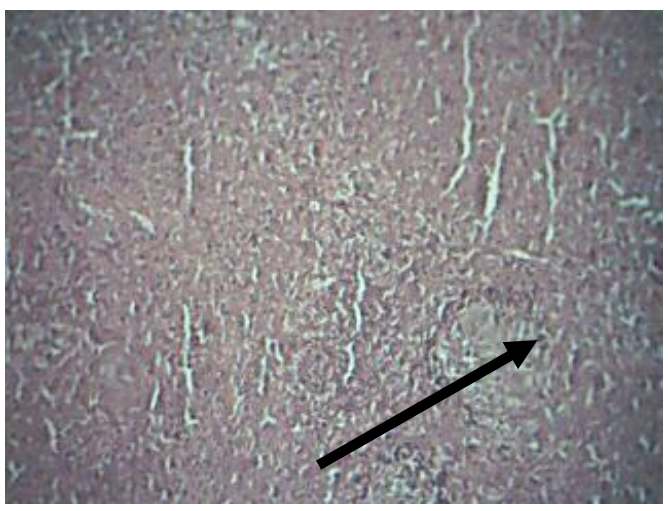

Fig 2 (C)

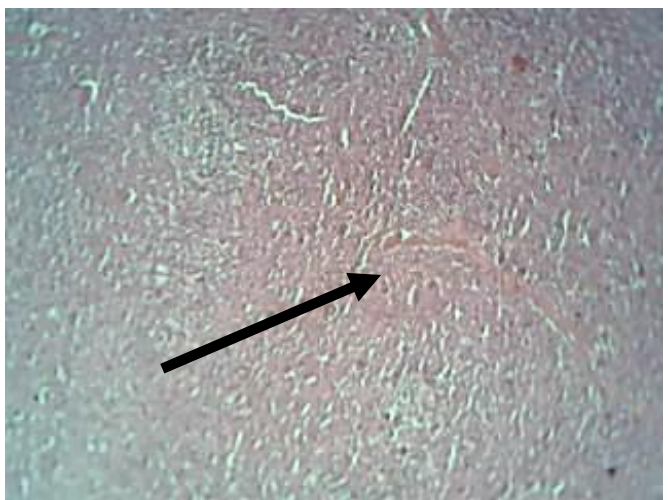

Fig 2 (D)

Photomicrographs of haematoxylin and eosin stained sections of rabbit pancrease; (A) Group represented degeneration of langerhans islets by alloxane monohydrate, (B), (C) and (D) fig. showed mild degeneration, $(\mathrm{H} \& \mathrm{E}, 10 \times)$. 


\section{Discussion}

Oxidative stress depicts the existence of products called free radicals and physiological conditions but become deleterious when not being quenched by the antioxidant systems ${ }^{(13)}$. There are convincing experimental and clinical evidences that the generation of reactive oxygen species is increased in both type of diabetes and that the onsets of diabetes is closely associated with oxidative stress ${ }^{(14)}$. Free radicals are formed disproportionately in diabetes by glucose autoxidation, polyol pathway and non-enzymatic glycation of protein ${ }^{(15)}$. Abnormally high levels of free radicals and simultaneous decline of antioxidant defense systems can lead to the damage of cellular organells and enzymes, increased lipid peroxidation and development of complications of diabetes mellitus ${ }^{(16)}$.In the present study, we examined oxidative stress pathway markers in the diabetic rabbits as compared to normoglycemic animals. From the results obtained it is evident that the diabetic rabbits had much higher glucose levels when compared with normoglycemic, the increase in blood glucose level and decreased insulin level depend upon the degree of $\beta$-cell destruction ${ }^{(17)}$. regression in body weight gain and increment the level of glycosylated hemoglobin was observed in the diabetic T2 animals and these conditions were directly proportional to the blood glucose level ${ }^{(18)}$. This suggest the increase in oxidative stress due to hyperglycemia and subsequent protein glycation as presented in bad result of body weight gain and glucose level of T2 group. Alloxane exert it's effect through it's reduction by glutathione to dialuric acid, in which redox recycling process generates ROS that damaged $\beta$-cell, furthermore transition metals such as iron and copper which are potentially involved in the generation of hydroxyl free radicals are also involved in alloxane mediated killing of beta cells ${ }^{(19)}$.Increment the activity of enzyme fatty acylecoenzyme A oxidase which resulted from hypoinsulinemia incites beta oxidation of fatty acids, resulting in lipid peroxidation ${ }^{(20)}$ that impairs membrane function by decreasing membrane fluidity and changing the activity of membrane-bound enzymes and receptors. The products of lipid peroxidation are harmful to most cells in the body and are associated with a variety of diseases, such as atherosclerosis and brain damaged $^{(21)}$, In our study significant increase $(\mathrm{p} \leq \mathrm{o} . \mathrm{o} 1)$ of cholesterol and triglyceride observed in the plasma of diabetic $\mathrm{T} 2$ rabbits.Our result refer to improvement in body weight gain and glucose concentration of antioxidants treated animals, as it present in T3 animals group, since vitamin $\mathrm{C}$ is an important antioxidant capable of scavenging oxygen free radicals, vit. $\mathrm{C}$ is structurally similar to glucose and can replace it in many chemical reaction and thus is effective in prevention of non enzymatic glycosylation of protein that improve body weight gain, in addition, vit. $\mathrm{C}$ act as regular of catabolism of cholesterol to bile acid this effect the reduction of cholesterol and triglyceride level in T3 group ${ }^{(22)}$. Our results also refer to improvement in $\mathrm{T} 4$ and T5 animals group, since vit. A and E share the same mechanism of free radical scavenging which may be have the same similar effect. Vit. A supplementation also may have an effect on chemical induced diabetes mellitus, furthermore it is of interest that all trans $\beta$-carotene, reduced lesion formation in hypercholesterolemic rabbirs, $\beta$-carotene is metabolized to retinoids which exert powerful effects on growth and differentiation via their interaction with two families of nuclear transcription factors, the retinoic acid receptors and retinoid $\mathrm{X}$ receptors, The retinoic acid receptor is activated by both all-trans retinoic acid and 9- cis retinoic acid, whereas the retinoid $\mathrm{X}$ receptor is selectively activated by 9 -cis retinoic acid raising the possibility that genes specifically controlled by the retinoic acid receptor may inhibit atherosclerosis. Retinoic acid regulates the expression in cultured cells of several proteins implicated in atherogenesis, including 
thrombomodulin and monocyte chemoattractant protein-1 ${ }^{(23)}$. also in view of it's antioxidant property It may as well delay complication arising from diabetes disease ${ }^{(24)}$.Vit. E also improve glucose concentration in T5 animals group, the excess glucose present in blood react with hemoglobin to form HbA1c (glycosylated hemoglobin) HbA1c is used as a marker for estimation the degree of protein glycation in diabetes mellitus (25), administration of $\alpha$-tocopherole to diabetic rabbit reduced the glycation of hemoglobin and thus decrease the level of glycosylated $\mathrm{Hb}$, thus normalize glycosylated $\mathrm{Hb}$, subsequently reduced glycated protein and improve body weight gain $^{(26)}$.Vitamin $\mathrm{E}$ also improve lipid peroxidation of histological cell membrane by potent scavenging super oxide and other free radicals ${ }^{(27)}$, In addition vit $\mathrm{E}$ increase the bioavailability of nitric oxide that play important role in restore endothelial function this had significant role in cholesterol and triglyceride reduction ${ }^{(28)}$.Glutathione peroxidase and superoxide dismutase are two antioxidant enzymes act as substrates for free radicals hydrogen peroxide and superoxide respectively, these enzymes are indicator for oxidative stress status in body and their concentration in tissues are more reliable indicator than concentration in blood, their

\section{References}

1. ADA (American Diabetes Association), (2005) Diagnosis and classification of diabetes mellitus. Diabetes Care 28 (suppl. 1), S37-S43.

2. Robertson, R. P., (2004) Chronic oxidative sress as a central mechanism for glucose toxicity in pancreatic islet beta cells in diabetes, J. Biol. Chem 279(41), 42351-42354.

3. West, I. C., (2000) Radicals and oxidative stress in diabetes. Diabetic Med. 17, 171-180.

4. Saxena AK, Srivastava P, Kale RK, Baquer NZ. (1993) Impaired antioxidant status in diabetic rat significant decrease in liver of diabetic T2 rabbits may be indicative of exhaustion of these enzymes as a consequence of increased oxidative stress (29). liver glutathione peroxidase and superoxide dismutase were negatively correlated with plasma glucose, cholesterol and triglyceride levels ${ }^{\left({ }^{30}\right)}$.The results of histopathological changes in diabetic group showed degenerative signs in liver and pancrease of diabetic rabbits, the increment of oxygen free radicals production is associated with low intracellular magnesium concentration and prior magnesium deplession make cell more sensitive to oxidative damage (31) that magnesium posses antioxidant properties by scavenging free radicals and affecting the rate of dismutation of superoxide ion ${ }^{(32)}$ While, the histopathological changes in T3, T4 and T5 groups revealed improvement in tissue lesion of liver and pancreas, Vit E has been demonstrated to protect against magnesium deficiencyinduced myocardial injury ${ }^{(33)}$, on the other hand the effect of vitamin $\mathrm{E}$ on intracellular magnesium content lead to reduction in intracellular calcium thus resulting in improved smooth vascular cell relaxation ${ }^{(34)}$. Vitamin $\mathrm{C}$ has also been studied in diabetes, It plays a major role in regenerating vitamin $\mathrm{E}$ from the $\alpha$ tocopheroxyl radical $^{(35)}$.

\section{(1)}

5

5. Maritim, A. C., Sanders, R. A., liver. Effect of vanadate. Biochem Pharmacol;45(3):539-542.

Watkins, J. B. (2003), Diabetes, oxidative stress and antioxidants: a review, J. of Biochem. And Molecul. Toxicology, , 17, 24-38.

6. Weber P, Bendich A, Machlin LJ.(1997) Vitamin E and human hea lth: Rationale for determining recommended intake levels. Nutrition;13(5):450-460.

7. Martinoli L, Di Felice M, Seghieri G, Ciuti M, De Giorgio LA, Fazzini A, Gori R, Anichini R, Franconi F. (1993) Plasma retinol and alpha-tocopherol concentrations in insulin-dependent diabetes 
mellitus: Their relationship to microvascular complications. Int J Vitam Nutr Res;63(2):87-92.

8. Asayama K, Hayashibe H, Dobashi K, Niitsu T, Miyao A, Kato K. (1989) Antioxidant enzyme status and lipid peroxidation in various tissues of diabetic and starved rats. Diabetes Res;12(2):85-91.

9. Cinar MG, Ulker S, Alper G, Evinc A.(2001) Effect of dietary vitamin $\mathrm{E}$ supplementation on vascular reactivity of thoracic aorta in streptozotocin-diabetic rats. Pharmacology;62(1):56-64.

10. Randall L. Davis, Christy L. Lavine, Melissa A. Arredondo, Patrick McMahon, and Thomas E. Tenner, Jr.(2002) Differential Indicators of Diabetes-Induced Oxidative Stress in New Zealand White Rabbits: Role of Dietar Vitamin E Supplementation Int. Jnl. Experimental Diab. Res., 3:185-192.

11. Pence, B. C., and Naylor, M. F. (1990) Effects of a single-dose ultraviolet radiation on skin superoxide dismutase, catalase, and xanthine oxidase in hairless mice. J. Invest. Dermatol., 95, 213-216.

12. Duncan, B. D. (1955). Multiple range and multiple $\mathrm{F}$ test. Biometrics. 11:1-42.

13. FANG, Y. Z., Yang, S., Wu, G.; (2002) Free radical, antioxidant and nutrition, Nutrition, , 18, 872890.

14. Johansen, J. S., Harris, A. K., Rychly, D.J. Ergul, A. (2005), oxidative stress and the use of antioxidants in diabetes: Linking basic science to clinical practice, Cardiovascular diabetology, , 4, 5-9.

15. Obrosova, I. G., Vanlteysen, C., Fathallah, L., Cao, X., Greene, D. A., Stevens, M. J., An (2002) aldose redactase inhibitor reverses early diabetes- induced changes in peripheral nerve function, FASEB J., , 16, 123125.

16. Maritim, A. C. Sanders, R. A 2 and J. B. Watkins;(2003) Diabetes, Oxidative Stress, and Antioxidants: A Review $J$. BIOCHEM MOLECULAR TOXICOLOGY Volume 17, Number 1,

17. Grover, J. K., Vats, V., Rathi, S. S. (2000), Anti-hyperglycemic effect of Eugenia jambolana and Tinospora cordifolia in experimental diabetes and their effects on key metabolic enzymes involved in carbohydrate metabolism, J. Ethnopharmacol., , 73, 461-470.

18. Yassin, D. Al., Ibrahim, K. A. (1981) Minor haemoglobin fraction and the level of fasting blood glucose, J. Fac. Med. Univ., Baghdad, 23, 373-380.

19. Malaisse, W.J., (1982). Alloxane toxicity of the pancreatic B-cell anew hypothesis. Bioc Hem. Pharmacol., 22:3527-353d4.

20. Horie, S., Ishii, H., Suga, T. (1981), changes in peroxisomal fatty acid oxidation in diabetic rat liver, $J$. Biochem., 90 1691-1696.

21. Acworth, I. N., Mccabe, D. R., Maher, T.(1997), The analysis of free radicals, their reaction products, and antioxidants, in: S. I. Baskin, H. Salem (Eds), Oxidents, antioxidants and free radicals, Taylor and Francis, Washington, DC, Chapter 2.

22. Mohammad. A. and Ahmad (2007), S. effect of vitamin Cbon blood glucose, serum lipids and serum insulin in type 2 diabetes patients. Indian J Med Res 126, November, pp 471-474.

23. Bum, T. C., M. S. Provick, S. H. Hohaus, B. J. Rollins, and D. G. Tenen. (1994). Monocyte chemoattractant protein-i is expressed in activated neutrophils and retinoic acid-induced human 
myeloid cell lines. Blood. 84:2776-2782.

24. Hogan, P., T. Dall and P. Nikolon, (2003) Economic costs of diabetes in the US in 2002. Diabetes care, 26:917-932.

25. Kaleem, M; Asif, M; Ahmed, Q. U; Bano, B; (2006) antidiabetic and antioxidant activity of Annona squamosa extract in streptozotocin-induced diabetic rats. Singapore Med J.; 47:670675.

26. Shirpoor, A.; Khadem, M. H; Salami, S; Ghaderi, F. P; Rasmi, Y (2007) Effect of vitamin $\mathrm{E}$ on oxidative stress status in small intestine of diabetic rat. World $J$. of gastroenterology, 28; 13(32): 4340-4344.

27. Costagliola $\mathrm{C}$ and Memzione, $\mathrm{M}$ (1990) Effect of vitamin $E$ on the oxidative state of glutathione in the plasma. Clin Physiol Biochem. 8:140-143.

28. Chin, J. H; Azhar, S; Hoffman, B. B.(1992). inactivation of endothelial derived relaxing factor by oxidized lipoprotein. $J$ Clin Invest; 89:10-8.

29. Kinalski, M., Telejko, B., Zarzkycki,W., Gorski, J., and Kinalska, I. (1998) The effect of vitamin $\mathrm{E}$ on antioxidant tissue activity in pregnant rats with streptozotocin-induced diabetes. Przegl. Lek., 55, 320-324.
30. Kakkar, R., Mantha, S. V., Radhi, J., Prasad, K., and Kalra, J. (1998) Increased oxidative stress in rat liver and pancreas during progression of streptozotocin induced diabetes. Clin. Sci. (cloch.) 94, 923-632.

31. Freedman, A.; Mac, I. T; Stafford, R. E (1992) Erythrocytes from magnesium-deficient hamsters display an enhanced susceptibility to oxidative stress. Am J. Phsiol. 262:C1371-C1375.

32. Afanas ev, I. B.; Suslova, T. B; Cheremisina, Z. P.; Abramova, N. E.; Korkina, L. G. (1995) Study of antioxidant properties of metal aspartates. Analyst; 120:859-862.

33. Weglicki, W. B.; Bloom, S.; Cassidy, M. M.; Freedman, A, M.; Atrackchi, A. H.; Dickens, B. F. (1992) Antioxidant and cardiomyopathy of $\mathrm{Mg}$ deficiency. Am $J$ Cardiovasc Pathol. 4:210-215.

34. Giuseppe, P.; Maria, R. T.; Michelangela, B.; Guido, A. Z.; Antonio, G.; Gina, V.; Emilia, R.; Michele, V. (2000) The J. of clini. Endocrino. And metabolism 85:109-115.

35. Kagan VE, Serbinova EA, Forte T, Scita G, Packer L. (, 1992) Recycling of vitamin $\mathrm{E}$ in human low density lipoproteins. J Lipid Res, 33, 385-397. 


\title{
دراسة مقارنة لبعض مضادات الاكسدة في تصحيح معلمات الاجهاد التاكسدي للار انب المصابة تجريبياً بلاء الصيد السكري مطي
}

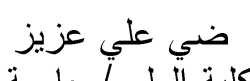 \\ كلية الطب البيطري/جاسم محمدة القادسية \\ كلية ألعلوم/ جلي عزيزة المثنى \\ افر اح جليل عبد المبن
}

الخلاصة

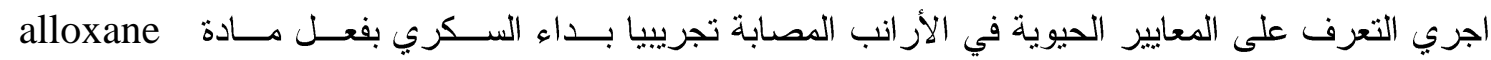

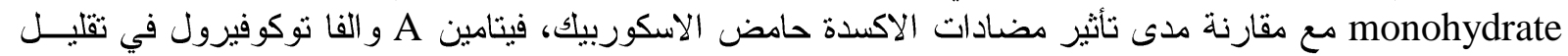

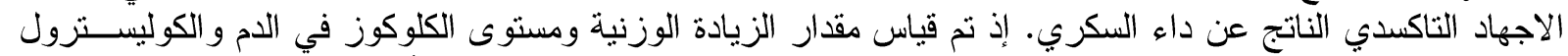

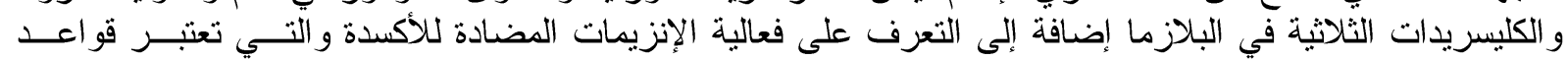

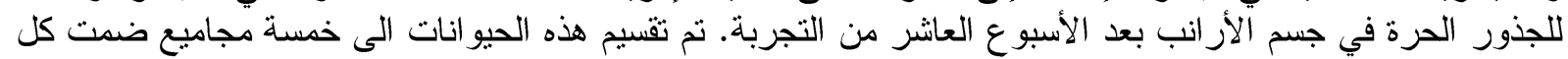

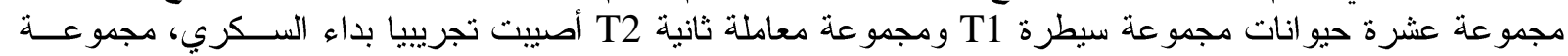

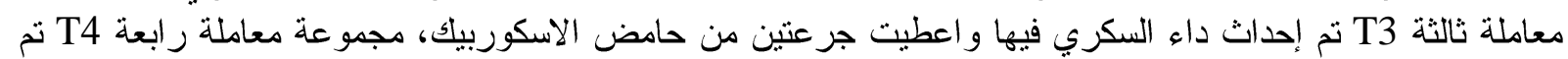

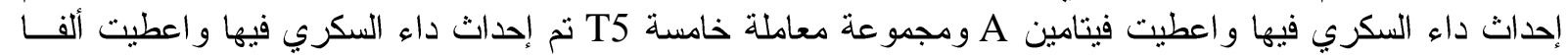

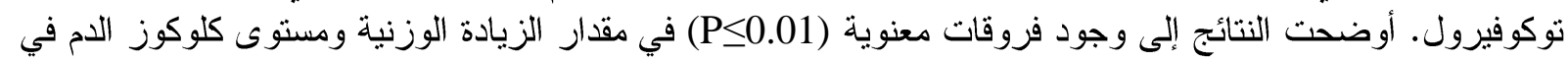

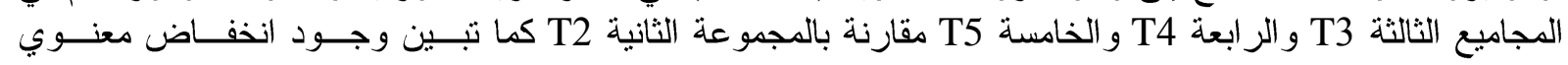

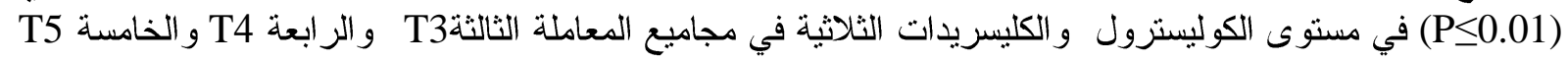

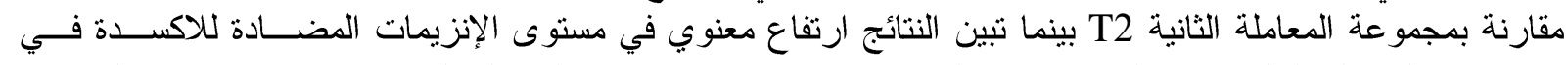

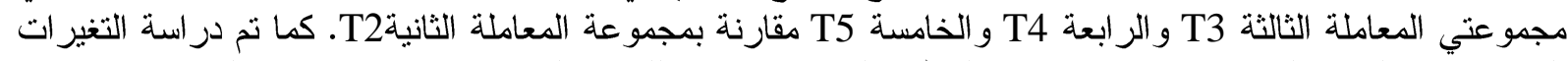

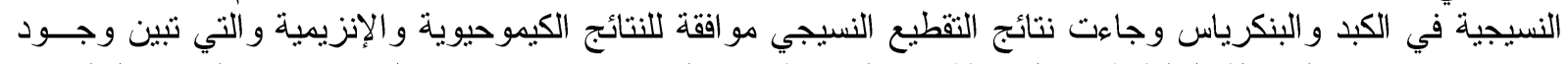

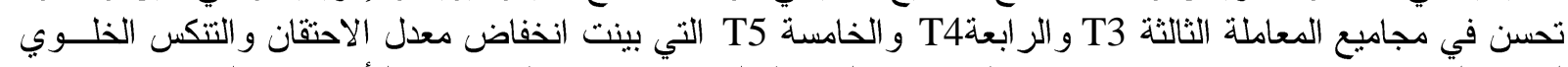

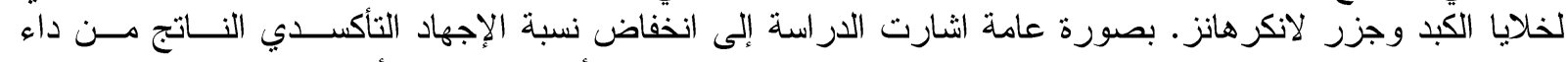

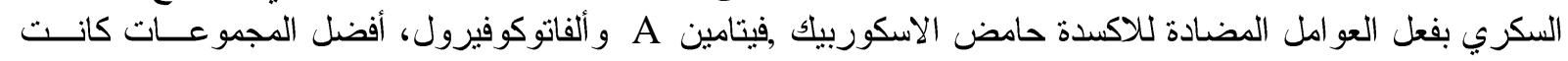
مجموعة المعاملة الخامسة. 